\title{
MRS Invites Nominations for the Von Hippel Award, Turnbull Lectureship, and MRS Medal
}

The Materials Research Society is seeking nominations for the Von Hippel Award, the Turnbull Lectureship, and the MRS Medal. The deadline for nominations is June 1, 2004. These awards will be presented at the 2004 MRS Fall Meeting, November 29-December 3, in Boston.

The MRS Awards Program recognizes outstanding contributors to the progress of materials research. Nomination forms and details about eligibility and nomination criteria are available from Materials Research Society, 506 Keystone Drive, Warrendale, PA 15086-7573, USA; phone 724-779-3004 ext. 102, fax 724-779-8313, or the MRS Web site at www.mrs.org. www.mrs.org/awards/

Von Hippel Award Acknowledges Outstanding Interdisciplinary Work in Materials Research

The Von Hippel Award, first presented to Arthur R. Von Hippel, whose interdisciplinary and pioneering research typified the spirit of the award, is the Society's highest honor. The recipient is recognized for brilliance and originality of intellect, combined with vision that transcends the boundaries of conventional scientific disciplines. The Award includes a \$10,000 cash prize, honorary membership in MRS, and a unique trophy - a mounted ruby laser crystal symbolizing the many-faceted nature of materials research.

Turnbull Lectureship Honors Career of an Outstanding Researcher and

Communicator

The David Turnbull Lectureship recognizes the career of a scientist who has made outstanding contributions to understanding materials phenomena and properties through research, writing, and lecturing, as exemplified by the life work of David Turnbull. While honoring the accomplishments of the recipient, the Turnbull Lectureship is intended to support and enrich the materials research community.
The recipient will give a technical lecture of broad appeal at a designated session of the 2004 MRS Fall Meeting. The Turnbull Lecturer will receive a $\$ 5,000$ honorarium and a citation plaque, along with travel expenses paid to enable the recipient to address MRS Sections and University Chapters and/or participate in the production of a video version of the lecture.

\section{MRS Medal Recognizes Recent}

Discovery or Advancement in

Materials Science

The MRS Medal offers public and professional recognition of an exceptional recent achievement in materials research. A medal will be awarded for a specific outstanding recent discovery or advancement that is expected to have a major impact on the progress of any materialsrelated field.

The award consists of a $\$ 3,000$ cash prize, an engraved and mounted medal, and a citation certificate.

\section{MRS Online}

\section{E-Mail Alerts www.mrs.org/alerts/}

Sign up for any of these FREE services today and let the Materials Research Society bring materials information to you!

\section{eMatters}

delivers a monthly "snapshot" of what's new in the materials research communityresearch news, important links, professional opportunities, and more

\section{MRS Table of Contents Alert}

delivers advance table-of-contents listings for JMR and MRS Bulletin

Just Published! Book Alert provides announcements of newly published proceedings and books from MRS

\section{MRS Meetings Alert}

offers regular updates on upcoming meetings and workshops from MRS - call for papers announcements, abstract submission deadlines, registration dates and discounts, program and speaker updates, etc.

\section{MRS Meeting Scene}

Can't attend an MRS Meeting? This e-mail will keep you abreast of each day's exciting activities and developments.

\section{MRS Public Affairs Alert}

provides occasional calls-to-action and/or summaries of current public-policy issues affecting the materials science and engineering communities

\section{Women in MSEE}

A mailing list for continuing discussion and information exchange on issues affecting women in the materials profession. Women and men are both welcomed to participate.

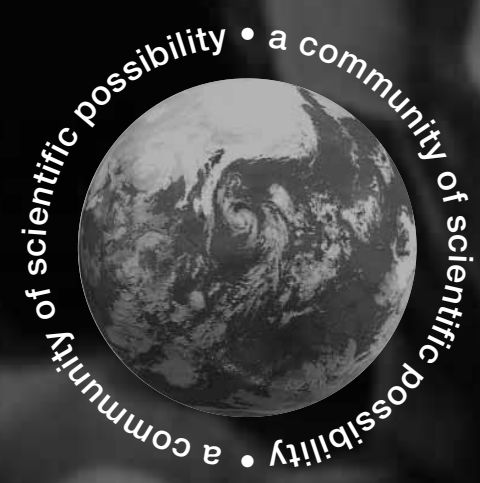

For more information, go to... www.mrs.org/alerts/ 